\title{
THE IMPORTANCE OF FIELD-MARGIN LOCATION FOR MAINTENANCE OF FOOD NICHES FOR POLLINATORS
}

\author{
Bożena Denisow ${ }^{1 *}$ \\ Małgorzata Wrzesień? \\ 'Department of Botany, University of Life Sciences in Lublin \\ 15 Akademicka Street, 20-950 Lublin, Poland \\ 2Department of Geobotany, Institute of Biology, Maria Curie-Skłodowska University, \\ 19 Akademicka Street, 20-033 Lublin, Poland \\ *corresponding author: bozena.denisow@up.lublin.pl \\ Received 02 July 2014; accepted 19 March 2015
}

\begin{abstract}
A bstract
Understanding the factors that have an impact on the diversity of forage flora in the agricultural landscape is a key issue in the maintenance and control of food niches for pollinators. Field margins are common linear structures in the agricultural landscape. In the present study, we evaluated the factors that exert an impact on the forage flora composition and on the diversity in field margins. The study was conducted in the $2010-2011$ time period across the agricultural landscape on the Lublin Upland of SE Poland. Data on the forage flora were obtained while making floristic charts along 45 transect plots $x 300 \mathrm{~m}$; the total length being $13500 \mathrm{~m}$. Multivariate ordination techniques (PCA and RDA) were employed to analyse forage-flora characteristics. Field margins represent valuable refuge areas for forage-species richness, but not for the abundance of forage species. On field margins, forage-species diversity benefits from the location of natural habitats (forests or meadows), primarily if the distance from these habitats is $<1000 \mathrm{~m}$ or the field acreage is $<10$ ha. The shift from heterogeneous habitats to a more homogeneous landscape causes a reduction of forage floral diversity. Due to lack of dense forage-species patches, the promotion of sowing nectariferous and/or polleniferous species seems to be a reasonable management method to enhance the quantitative food niche on field margins and to support the conservation of pollinators in the areas surrounding farms.
\end{abstract}

Keywords: agricultural landscape, bee conservation, bee-flora diversity, man-made habitats, natural habitats.

\section{INTRODUCTION}

Currently, the decline in the diversity and abundance of insect pollinators is a global issue (e.g. SteffanDewenter et al., 2005; Potts et al., 2010). A drastic decline in both honey bee and wild bee populations is a serious threat to the stability and yield of food crops, and thus, a threat to human nutrition (Delaplane and Mayer, 2000; Gallai et al., 2009). The pollinator decline is also likely to have serious consequences for general biodiversity (Corbet, 2000). Globally, pollinators are responsible for the maintenance of natural ecosystems, as approximately 30,000 plant species rely on their service for efficient reproduction (Kevan, 1999).

Pollinator shortages are particularly severe in landscapes that have been altered by human activities, i.e. in agricultural areas. The degradation and/or fragmentation of habitats for bees (Banaszak, 1992) and the negative effect of pesticides (Johnson et al., 2010), potentially contribute to the loss of pollinators. Severe food shortages should also be mentioned among the factors that induce pollinator decline (Delaplane and Mayer, 2000; Kleijn and van Langevelde, 2006). The chronic scarcity of nutrition is due to (i) the increased area of monocultures, with a dominance of nectarless cereals in the crop structure (> 70\%) (Chmielewski and Węgorek, 2003), (ii) highly cumulative forage with mass-flowering in a short period, e.g. ripe or orchard crops (Kleijn and van Langevelde, 2006), or (iii) multi-directional agricultural technologies, i.e. application of fertilisers and herbicides, with negative effects on wild flora and displacement of flower-rich plant communities (Corbet, 2000; Denisow and Wrzesień, 2007; Decourtye et. al., 2010). 
If the alarming decline in honey bee populations continues, wild pollinators will become increasingly important (Potts et al., 2010). A modern landscape design must first focus on how to provide ecological integrity to a mosaic of crop and uncropped areas, and how to structure a bee-friendly landscape. It is difficult to define, though, how many wild-plant patches are needed and how they should be distributed within agricultural landscapes to secure food niches for pollinators (Banaszak, 1992; Lonsdorf et al., 2009; Bartomeus et al., 2014).

The agricultural landscape covers about half of Europe's territory, although a broad range (10 - 80\%) refers to particular countries, e.g. in Poland, cultivated fields constitute over $54 \%$ of the area (Chmielewski and Węgorek, 2003). In the agricultural landscape, field margins are common structures (Marshall and Moonen, 2002). The field margins represent an important area that serves as a suitable environment for many groups of organisms (Banaszak, 1992; Corbet, 2000; Chmielewski and Węgorek, 2003; Decourtye et al., 2010), including different groups of plants (Denisow and Wrzesień, 2007). Moreover, field margins provide two basic types of resources necessary for the maintenance of wild pollinators: nesting substrates and floral resources (Banaszak, 1992; Marshall and Moonen, 2002). An understanding of the nectariferous and polleniferous flora distribution within field margins may provide important data that allow conservation of pollinators on the landscape scale. There were even more specific goals in this study: (i) to determine forage-species richness and diversity within field margins; (ii) to analyse the species composition and distribution in relation to the distance from natural habitats (forests, meadows, or their absence) and in relation to the acreage of fields to which the margins are adjacent. Additionally, we evaluated the ecological factors that have an impact on the occurrence of bee flora within field margins.

\section{MATERIAL AND METHODS}

\section{Study area}

The investigations were carried out during the 2010-2011 time period, and covered four municipalities located on the Lublin Upland, SE Poland: Lubartów $\left(22^{\circ} 36^{\prime} \mathrm{E}, 5^{\circ} 28^{\prime} \mathrm{N}\right)$, Niemce $\left(22^{\circ} 38^{\prime} \mathrm{E}\right.$, $\left.51^{\circ} 21^{\prime} \mathrm{N}\right)$, Bychawa $\left(22^{\circ} 32^{\prime} \mathrm{E}, 51^{\circ} 01^{\prime} \mathrm{N}\right)$, and Jastków $\left(22^{\circ} 26^{\prime} \mathrm{E}, 51^{\circ} 18^{\prime} \mathrm{N}\right)$ (Fig. 1A). The region is

A

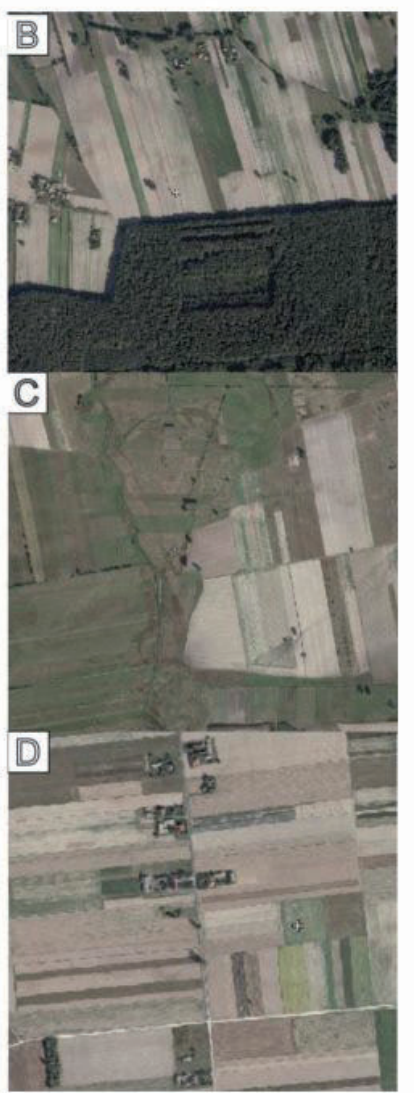

Fig. 1. Map of Lublin Upland showing the study area; A - the location of municipalities 1 - Lubartów, 2 - Niemce, 3 - Jastków, 4 - Bychawa. Habitat types in the field margins: $\mathrm{B}$ - forests, $\mathrm{C}$ - meadows, D - >1000 m from natural habitats. 
highly undulated at $180-252 \mathrm{~m}$ above sea level. The average yearly precipitation in the research area is $572 \mathrm{~mm}$, with a mean annual temperature of $7.4^{\circ} \mathrm{C}$. Most soils are clay-dusty and sandy-dusty or loess-origin brown and grey-brown soils (Turski et al., 1993). The research area was characterised by a large proportion of arable land, interposed with patchily distributed fragments of grasslands (2.7-19.4\% of the area coverage) and forests (22.3\%-36.8\% of the area coverage). Farming and gardening build up the mosaic structure of the landscape characteristic for the eastern part of Poland, with fields (c.a. 7.5 ha in acreage) and field margins among the fields (Fig. 1B - D). Cereals covered most of the cultivated area $(50-68 \%$ of the crop structure) and c.a. $12-18 \%$ of the crop structure was occupied by root crops (potato and sugar beet fields). Therefore, the abundant nectar and pollen flow from crop plants was observed only in May, during orchard and/or rape blooming.

\section{Data collection and preparation}

Within the area of each municipality, we made walks along 15 transects, each transect was $300 \mathrm{~m}$ long (= in total 45 transect plots, $13500 \mathrm{~m}$ in length were analysed). The transects ranged in width from 1.3 to 2.8 meters, the average being $2.2 \mathrm{~m}$. The transects were located on field margins (= strips of land along the borders of crop fields). The geographic position of each transect plot was recorded with a differential GPS. The field survey was conducted from May to mid-August when spring flowers were still present and recognisable and the seedlings of summer species were identifiable. The method of phytosociological relevés was employed. The frequency and abundance of each vascular plant species in a particular transect plot was evaluated using the Braun-Blanquet approach (1964). The characteristics of different species were considered: the botanical family, type of forage - nectar and/or pollen, flower type (actinomorphic vs. zygomorphic; entomophilous vs. anemophilous), life-form (perenials vs. biennials vs. annuals), dispersal mechanism (long-distance: anemochorous, zoochorous vs. short-distance: ballistochorous type) to make the flora analysis more complex. The relevant data were obtained from Kleyer et al. (2008). The list of bee species was established on the basis of literature data (Kołtowski, 2006; Denisow and Wrzesień, 2007; Denisow, 2011) and according to our own observations. The taxonomic system and plant nomenclature followed Mirek et al. (2002).
Prior to statistical analyses, the transect plots were categorised based on: (1) the type of the habitat in the surrounding area, and (2) the acreage of the fields to which the field margins are adjacent. The transect plots were also categorised according to the distance criteria, as located at: (i) 50 - $500 \mathrm{~m}$ from forests, (ii) 50 - $500 \mathrm{~m}$ from meadows, (iii) >1000 m from natural habitats. The field acreage categories were comprised of: (i) small size 3 - 5 ha, (ii) mid-size 5.1 - 10 ha, and (iii) large size >10.1 ha. Information on the current field size and field margin distance from the habitat type was based on detailed digital cadastral data as well as high-resolution IR orthophotographs (taken on 12 July, 2010 and 23 May, 2011; pixel resolution $1 \mathrm{~m}$ ).

\section{Data analyses}

The flora on the transect plots was compared based on three types of indices, focusing on (i) species richness $-S=n_{i}$, where $n_{i}=$ species $i$, (ii) species diversity with the Shanon-Wiener index $H^{\prime}=-\sum p_{i} \log _{2} p_{i}$, where $p_{i}=$ frequency of the species i, and (iii) species evenness with the Pielou index $J^{\prime}=H^{\prime} / \mathrm{lnS}$, defined as the ratio of the observed diversity to the maximum diversity, where: $\mathrm{S}=$ the number of species and $\mathrm{H}_{\max }=\ln \mathrm{S}$. J' is constrained between 0 and 1; the less variation in communities between the species, the higher J' is. To calculate the indices the MVSP package was used (Kovach, 2005). The mean and the SD (standard deviation) were computed and the values obtained were compared. The Kruskal-Wallis non-parametric test was employed to test the significance of differences in the above-mentioned indices (Stanisz, 2007). Pearson's correlation coefficient ( $r$ ) was applied to measure the strength of the relationship between the forage species richness and the distance of field margins from natural habitats. Statistica software package version 10 developed by StatSoft Krakow was applied for these analyses.

Multivariate ordination techniques were also used to examine the differences in the flora composition on the field margins. Due to the homogeneous nature of the data $(S D<2)$, a linear model Principal Components Analysis (PCA) was used. Redundancy Analysis (RDA) with forward selection and associated Monte Carlo significance permutation tests (499 permutations) were employed to relate differences in the species composition with environmental variables (Canoco 5.0, ter Braak and Šmilauer, 2012). Three environmental variables describing the location of the field margins within the agricultural landscape, i.e. HABITAT, DISTANCE, and SIZE, were tested (Tab. 1). 


\begin{tabular}{|c|c|}
\hline Variable & Variable code \\
\hline \multicolumn{2}{|c|}{ Location of the field margins } \\
\hline $\begin{array}{l}\text { Type of habitat present in the } \\
\text { surrounding of field margins }\end{array}$ & HABITAT \\
\hline $\begin{array}{l}\text { Distance of field margins from natural } \\
\text { habitat }\end{array}$ & DISTANCE \\
\hline $\begin{array}{l}\text { The acreage of field close to field } \\
\text { margins }\end{array}$ & SIZE \\
\hline \multicolumn{2}{|c|}{$\begin{array}{c}\text { Ecological criteria based on indicator values } \\
\text { (EIV) }\end{array}$} \\
\hline Light & $\mathrm{L}$ \\
\hline Temperature & $\mathrm{T}$ \\
\hline Soil moisture & $W$ \\
\hline Soil/water $\mathrm{pH}$ & $\mathrm{R}$ \\
\hline Trophy & $\mathrm{Tr}$ \\
\hline
\end{tabular}

Table 1.

In the next step, we identified the ecological factors that had an impact on the species diversity among the field margins. The ecological indicator values (EIV) were calculated for all the species recognised in each transect, using the Ellenberg system adopted for Polish conditions by Zarzycki et al. (2002). We took into account 5 environmental variables related to ecological indicator values describing the most typical habitat conditions within agricultural transformed areas - light $(L)$, temperature $(T)$, soil moisture $(W)$, soil/water $\mathrm{pH}(\mathrm{R})$, and trophy value (Tr). The Tr value means the content of different nutrients, particularly $\mathrm{N}, \mathrm{K}, \mathrm{Mg}, \mathrm{Ca}$, and $\mathrm{P}$, make the habitat fertile in different ways. The share of species with a specific indicator value in each transect plot was determined using a modified formula for the weighted averages.

$$
W_{A}=\frac{\sum_{i=1}^{n}\left(A_{i}^{2} \times I_{i}\right)}{\sum_{i=1}^{n} A_{i}^{2}}
$$

where: WA - weighted average,

$A_{i}$ - abundance of cover of the $i$-th species in a given field margin transect,

$I_{i}$ - ecological indicator value for the $i$-th species, $n$ - number of species in the field margin transect.

The data from the sampling periods were pooled. The level of statistical significance to measure the differences between the means for all the analyses was at $P=0.05$.

\section{RESULTS}

In the study, 275 vascular plant species were sampled and identified in the total dataset, of which 225 species (81.5\%) were identified as bee species. The number of bee species in the particular transect plots was variable (mean $=97 \pm 29.7$ SD), ranging from 36 to 160 . Species yielding both nectar and pollen predominated (203 species - 90.2\%). Pollen as the floral reward (= no nectar) was offered by 22 species $(9.7 \%)$ of the noted bee flora. The frequency of bee species in the analysed transect plots ranged from 2.2 to $100 \%$ and constituted: $>50 \%$ - 15 species, 10 - $50 \%$ - 69 species, $<10 \%$ 47 species; the other 94 species were sporadically noted.

Most bee species, i.e. 129 (57.3\%), were not-abundant, and covered $<10 \%$ of the transect plots; 80 species $(35.6 \%)$ covered $10-50 \%$ of the plot area, and 16 species (7.1\%) represented $>50 \%$ of the cover in the transect plots.

The bee species belonged to 33 botanical families. The ratio of actinomorphic to zygomorphic flowers was approximately $2: 1$, an average of $157 \pm 11.3$ SD vs. $68 \pm 7.3 \mathrm{SD}$ in the entire forage flora. The richest in bees species were the families: Asteraceae (50 species - 22.2\%), Fabaceae (23 species $10.2 \%$ ), Rosaceae (20 species - $8.9 \%$ ), Lamiaceae (18 species $-8.0 \%$ ), Apiaceae ( 11 species $-4.8 \%$ ), and Brassicaceae (10 species - 4.4\%). The ratio of perennials to biennials to annuals was approximately 4:1:1.5 (averaged $135 \pm 7.3$ vs. $34 \pm 9.3$ vs. $56 \pm 14.1$ SD species in the entire bee flora, respec- 
tively). Significantly more perennials were found on field margins located close to natural habitats compared with those located $>1000 \mathrm{~m}$ from natural habitats (Kruskal-Wallis test for habitat effect: $\mathrm{H}=8.97, \mathrm{P}=0.031$ ). No field-size effect was found for the species life-form $(H=2.34, P=0.182)$. Most bee species (86\%) represented the anemochorous dispersal mode.

The location of the field margins in the landscape affected the bee species richness $(H=7.95$, $P=0.018 ;$ Tab. 2). The mean number of species on field margins located $>1000 \mathrm{~m}$ from natural habitats was significantly lower (approx. 10 - 40\%) compared with margins located in the surroundings of natural habitats. The richness of bee species decreased significantly if the distance from natural habitats increased (Pearson correlation $r=-0.480, p<0.05$; Fig. 2). When the total flora was taken into consideration, the $\mathrm{H}^{\prime}$ and $\mathrm{J}$ ' indices indicated a dominance of particular species on field margins located $>1000 \mathrm{~m}$ from natural habitats compared with margins located in the surroundings of natural habitats (for $\mathrm{H}^{\prime}$ index: $H=6.72, P=0.021$, for $]^{\prime}$ index $H=12.3, P=0.015$; Tab. 2). The bee species diversity on field margins located in a homogenous agrocenose landscape (>1000 $\mathrm{m}$ from natural habitats) differed from that noted on field margins in the surroundings of natural habitats (for $\mathrm{H}^{\prime}$ index: $\mathrm{H}=8.26, \mathrm{P}=0.022$ ), but the species evenness was equal in the entire landscape (for J' index: $\mathrm{H}=2.3, \mathrm{P}=0.341$ ).

The size of the field to which the field margins are adjacent had a significant effect on the bee species richness $(H=12.07, P=0.021)$ and diversity (for $H^{\prime}$ index: $H=21.14, P=0.038$, for J' index: $H=11.38$, $P=0.043)$. No differences were noted between margins adjacent to small and mid-size fields (Tab. 3). It was confirmed by RDA analysis that there was an impact of the studied environmental factors (HABITAT, DISTANCE, SIZE) on the composition and diversity of bee flora noted on the field margins.

Table 2.

Comparison of plant species richness $(\mathrm{S})$ and diversity indices $\left(\mathrm{H}^{\prime}, \mathrm{J}^{\prime}\right)$ calculated for total and forage flora, noted on field margins. The means \pm SD (standard deviation) are shown

\begin{tabular}{|c|c|c|c|c|c|c|}
\hline \multirow{3}{*}{$\begin{array}{l}\text { Habitat } \\
\text { type }\end{array}$} & \multicolumn{2}{|c|}{$\begin{array}{c}\text { Species number } \\
\mathrm{S}\end{array}$} & \multicolumn{2}{|c|}{$\begin{array}{c}\text { Shannnon-Wienner } \\
\mathrm{H}^{\prime}\end{array}$} & \multicolumn{2}{|c|}{$\begin{array}{c}\begin{array}{c}\text { Evenness } \\
\mathrm{J}^{\prime}\end{array} \\
\end{array}$} \\
\hline & Total & Forage & Total & Forage & Total & Forage \\
\hline & Mean \pm SD & Mean \pm SD & Mean \pm SD & Mean \pm SD & Mean \pm SD & Mean \pm SD \\
\hline $\begin{array}{c}\text { Forest } \\
50-500 \mathrm{~m}\end{array}$ & $157.2_{a} \pm 41.8$ & $127.5_{a} \pm 32.5$ & $2.17_{\mathrm{a}} \pm 0.05$ & $2.08 \pm 0.05$ & $0.990_{\mathrm{a}} \pm 0.07$ & $0.911_{\mathrm{a}} \pm 0.08$ \\
\hline $\begin{array}{c}\text { Meadow } \\
60-500 \mathrm{~m}\end{array}$ & $114.3_{b} \pm 23.7$ & $12.2_{a} \pm 26.1$ & $2.03_{a} \pm 0.09$ & $1.92_{b} \pm 0.9$ & $0.991_{\text {a }} \pm 0.05$ & $0.932_{a} \pm 0.04$ \\
\hline $\begin{array}{l}>1000 \mathrm{~m} \text { from } \\
\text { natural habitat }\end{array}$ & $98.0_{c} \pm 22.06$ & $73.6_{b} \pm 19.7$ & $1.96_{b} \pm 0.5$ & $1.82_{c} \pm 0.13$ & $0.788_{b} \pm 0.31$ & $0.910_{\mathrm{a}} \pm 0.12$ \\
\hline
\end{tabular}

The values indicated by the same small letter within columns are not statistically different, according to the KruskalWallis test.

Table 3.

Comparison of plant species richness $(\mathrm{S})$ and diversity indices $\left(\mathrm{H}^{\prime}, \mathrm{J}^{\prime}\right)$ calculated for total and forage flora noted on field margins associated with three types of field acreages.

The means \pm SD (standard deviation) are shown

\begin{tabular}{ccccccc}
\hline & \multicolumn{2}{c}{ Species number } & \multicolumn{2}{c}{ Shannon-Wienner } & \multicolumn{2}{c}{$\begin{array}{c}\text { Evenness } \\
\mathrm{J}^{\prime}\end{array}$} \\
\cline { 2 - 6 } Field acreage & Total & Forage & Total & Forage & Total & Forage \\
\cline { 2 - 6 } & Mean \pm SD & Mean \pm SD & Mean \pm SD & Mean \pm SD & Mean \pm SD & Mean \pm SD \\
\hline $\begin{array}{c}\text { Small } \\
3 \text { - } 5 \text { ha }\end{array}$ & $140.5_{\mathrm{a}} \pm 41.8$ & $111.8_{\mathrm{a}} \pm 24.9$ & $2.19_{\mathrm{a}} \pm 0.08$ & $2.01_{\mathrm{a}} \pm 0.14$ & $0.991_{\mathrm{a}} \pm 0.04$ & $0.990_{\mathrm{a}} \pm 0.03$ \\
\hline $\begin{array}{c}\text { Mid } \\
5.1-10 \text { ha }\end{array}$ & $117.4_{\mathrm{b}} \pm 35.5$ & $95.8_{\mathrm{ab}} \pm 36.1$ & $2.04_{\mathrm{a}} \pm 0.14$ & $1.93_{\mathrm{b}} \pm 0.4$ & $0.990_{\mathrm{a}} \pm 0.05$ & $0.991_{\mathrm{a}} \pm 0.04$ \\
\hline $\begin{array}{c}\text { Big } \\
>10.1 \text { ha }\end{array}$ & $104.0_{\mathrm{c}} \pm 26.8$ & $80.9_{\mathrm{b}} \pm 16.1$ & $1.98_{\mathrm{b}} \pm 0.5$ & $1.87_{\mathrm{c}} \pm 0.3$ & $0.788_{\mathrm{b}} \pm 0.31$ & $0.990_{\mathrm{a}} \pm 0.06$ \\
\hline
\end{tabular}

The values indicated by the same small letter within columns are not statistically different, according to the KruskalWallis test. 
The biplot diagram distinguished three specifically concentrated sets of field margins, indicating the differences in the species composition depending on the type of habitat in the surrounding area (forest vs. meadow vs. $>1000 \mathrm{~m}$ from natural habitat).
The first two axes displayed in the ordination diagram explained $19.0 \%$ of the variation. The total variation explained by all the axes was $21.7 \%$ (Fig. 3).

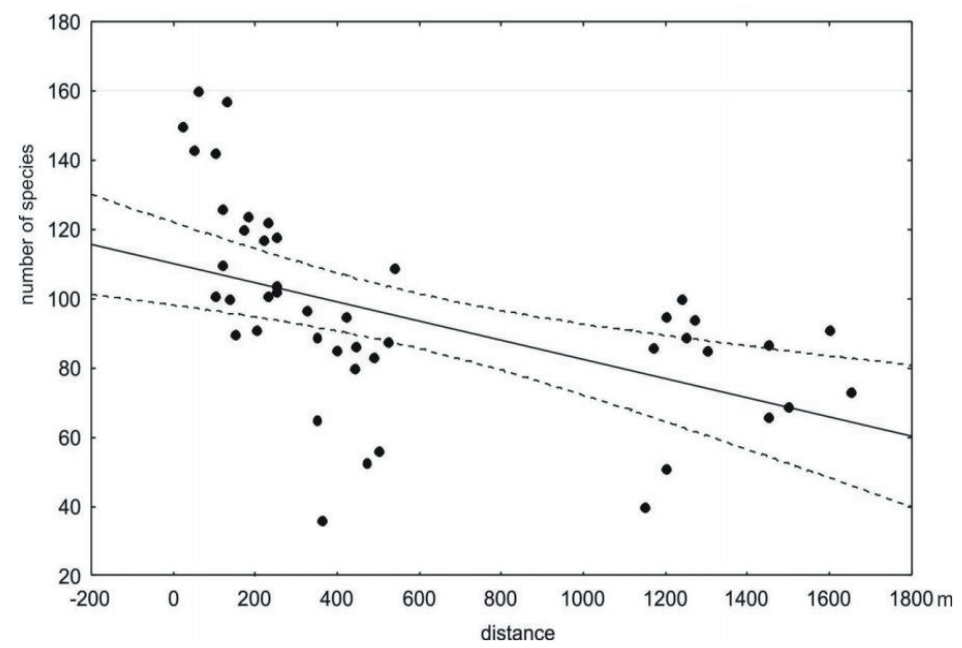

Fig. 2. The Paerson's correlation between the number of bee species on field margins and the distance from natural habitats.

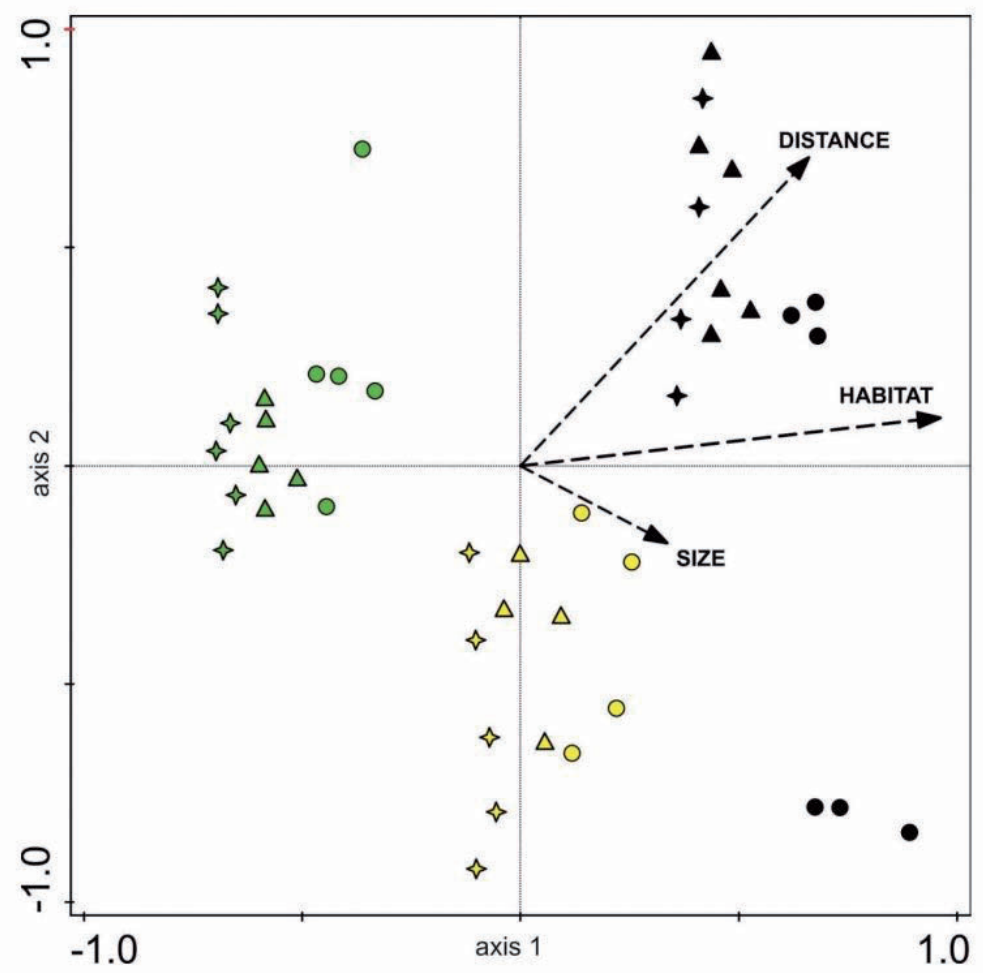

Fig. 3. Ordination biplot diagram of the redundancy analysis (RDA) for the 2010 - 2011 time period based on the species matrix comprising the flora which occurred on field margins. Each point refers to the field margins location within agricultural landscape studied. Green points correspond to the location 50 - $500 \mathrm{~m}$ from forests, yellow points - 50 - $500 \mathrm{~m}$ from meadows, and black points $>1000 \mathrm{~m}$ from natural habitats. Field size graphs - small, - mid, - big. Vector labels refer to environmental variables (see Table 1 for definition). Eigenvalues: Axis 1 - 0.152, Axis $2-0.038$. The diagram explains $21.7 \%$ of total variance. Simple term effects: HABITAT - $14.3 \%, P=0.002$; DISTANCE $-8.7 \%, P=0.002$; SIZE $4.1 \%, P=0.032$. Conditional effects: HABITAT $-14.3 \%, P=0.002$; DISTANCE $-4.0 \%, P=0.006$; SIZE $-3.4 \%, P=0.008$. 


\section{J. APIC. SCl. VOL. 59 NO. 12015}

In the entire dataset, only 16 bee species were revealed over $50 \%$ of the cover on the transect plots. These bee species preferred field margins located in the natural habitat surroundings (Fig. 4). The first two axes displayed in the ordination diagram explained $30.6 \%$ of the variation. The total variation explained by all the axes was $42.0 \%$. Every environmental factor related to the ecological criteria studied, exerted a significant impact on the occurrence of bees species that formed dense patches.

Irrespective of the location of the field margins across the landscape, the proportion of anemophilous species in the transect cover was high (ranging from $32-80 \%$ ). Among anemophilous plants, the species from the Poaceae, Amaranthaceae, and Polygonaceae families, as well as Artemisia vulgaris, Amaranthus retroflexus, Urtica dioica, or Descurainia sophia were most frequently noted.

From within the entire landscape, the location of the field margins affected the number of species flowering in the particular periods of the growing season ( $H=43.2, P=0.023$ ) (Fig. 5). In the period from early spring till early summer, the number of bee species in bloom was the lowest on margins located $>1000 \mathrm{~m}$ from natural habitats. The highest number of bee species in bloom was noted here, in summer and the late summer periods. Irrespective of the location of the field margins across the landscape, the bee species flowering in the early spring and spring period were very weak, on average 4.4 and 19.9 species, respectively.

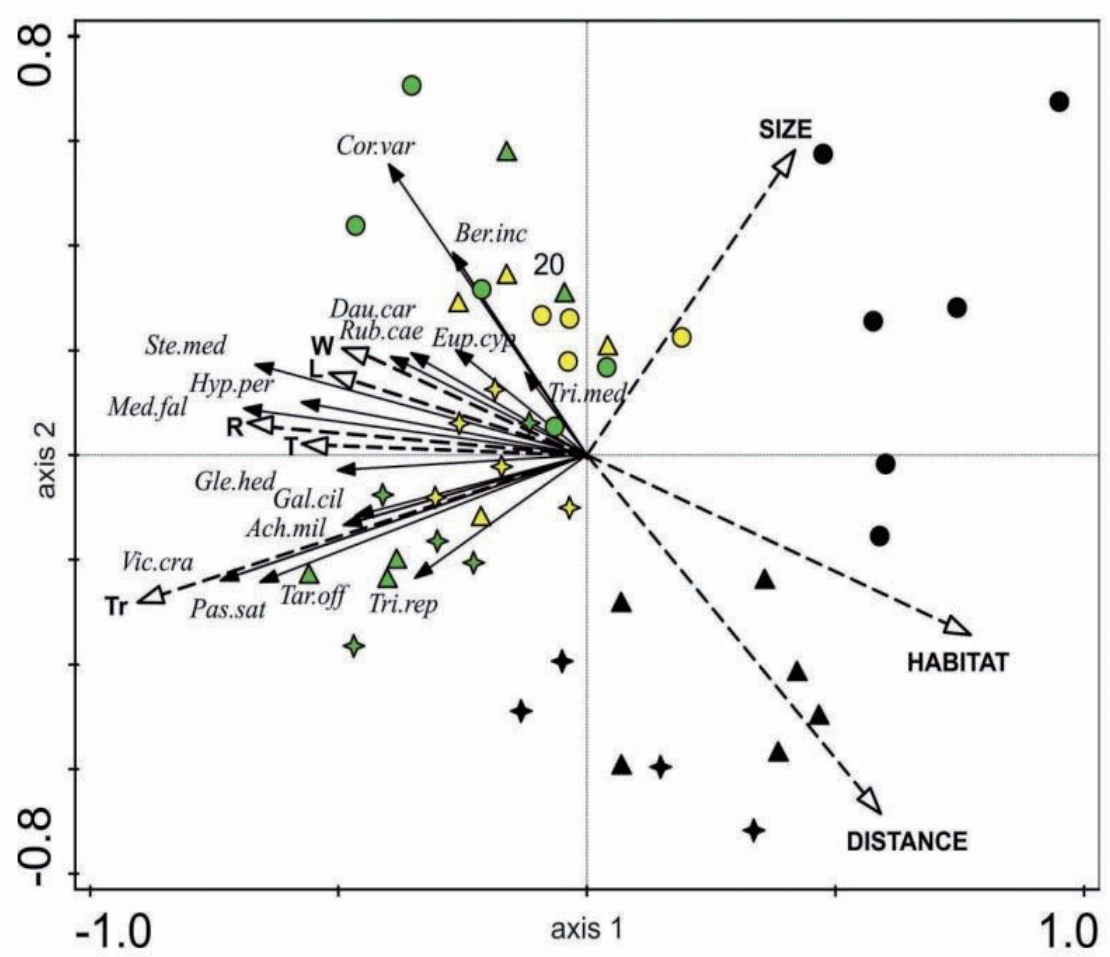

Fig. 4. Ordination triplot diagram of the redundancy analysis (RDA) for the 2010 - 2011 time period based on the species matrix comprising the flora which occurred on field margins. Each point refers to the field margins location within the entire studied agricultural landscape and field size (see fig. 3 for graph explanations). Vector labels refer to forage species selected for the highest frequency and $>50 \%$ cover, and to environmental variables (see Table 1 for definition). Eigenvalues: Axis $1-0.25$, Axis $2-0.05$. The diagram explains $42 \%$ of the total variance. Simple term effects: HABITAT $-16.7 \%, \mathrm{P}=0.002$; DISTANCE $-11.7 \%, \mathrm{P}=0.002 ; \mathrm{SIZE}-7.2 \%, \mathrm{P}=0.006 ; \mathrm{Tr}-21.5 \%$, $P=0.002 ; R-12.8 \%, P=0.002 ; T-10.0 \%, P=0.002 ; L-8.7 \%, P=0.006 ; W-8.5 \%, P=0.004$. Conditional effects: HABITAT $-5.9 \%, P=0.002 ;$ DISTANCE - 3.8\%, $P=0.022 ;$ SIZE $-2.8 \%, P=0.100 ; \mathrm{Tr}-21.5 \%, P=0.002$; $R-1.9 \%, P=0.290 ; T-1.6 \%, P=0.042 ; L-1.1 \%, P=0.69 ; \mathrm{W}-3.3 \%, P=0.06$. Explanations: Ecological indicator values abbreviations: $\mathrm{L}$ - light, $\mathrm{T}$ - temperature, $\mathrm{R}$ - soil $\mathrm{pH}, \mathrm{Tr}$ - trophy, $\mathrm{W}$ - soil moisture. Species abbreviations: Ach.mil - Achillea millefolium; Ber.inc - Berteroa incana; Cor.var - Coronilla varia; Dau.car - Daucus carota; Eup.cyp Euphorbia cyparissias; Gal.cil - Galinsoga ciliata; Gle.hed - Glechoma hederacea; Hyp.per - Hypericum perforatum; Pas.sat - Pastinaca sativa; Med.fal - Medicago falcata; Ste.med - Stellaria media; Rub.cae - Rubus caeasius; Tri. med - Trifolium medium; Tar.off - Taraxacum officinale; Tri.rep - Trifolim repens; Vic.cra - Vicia cracca. 


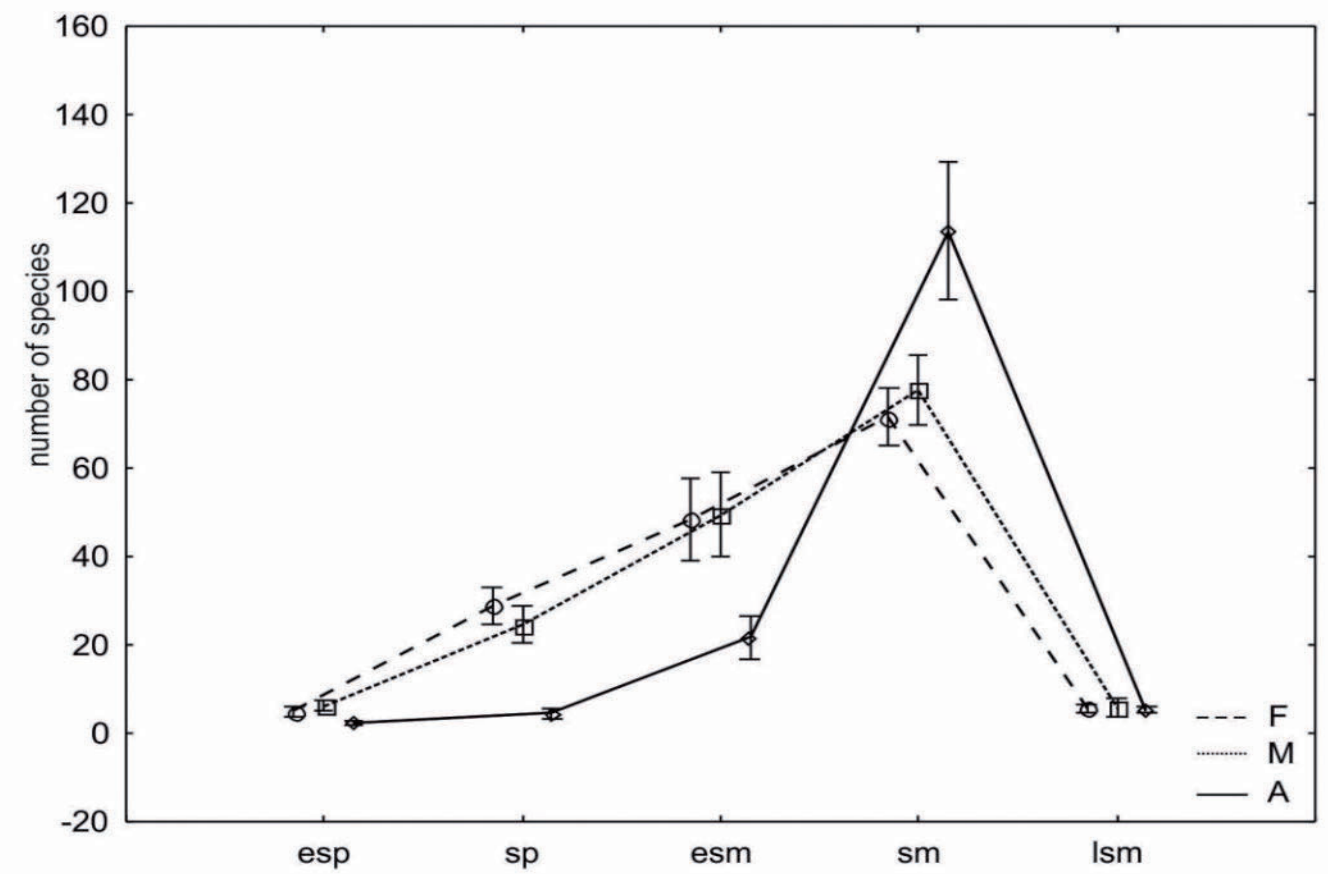

Fig. 5. The number of bee species in bloom during consecutive phenological periods of the growing season: esp - early spring, sp - spring, esm - early summer, sm - summer, Ism - late summer, and noted on field margins associated with three different types of habitats, studied on the Lublin Upland, SE Poland. Means for 2010-2011. Vertical bars indicate $95 \%$ confident intervals. Abbreviations: $F$ - forests, $M$ - meadows, A - >1000 m from natural habitats.

\section{DISCUSSION}

Our study represents an important step in evaluating field margins as a source of bee flora, using spatial biplot and triplot analyses. We have confirmed the great importance of field margins in bee flora richness (Wrzesień and Denisow, 2007; Decourtye et al., 2010), but not in bee species abundance. The value of non-cropped areas for bees is clearly dependent on the quantity of food resources available to the insects (Carreck and Williams, 1997; Delaplane and Mayer, 2000). Our study unequivocally revealed that a majority of bee species were not abundant or occurred only as scarce clumps of individuals, and only 16 bee species formed dense patches. Hence, we consider that the bee species present on field margins energetically contribute relatively little to the pollinators' diet compared with the contribution of mass flowering entomophilous crops. Westphal et al. (2003) documented nectariferous flowering crops as major energetically rewarding resources for bees, and indicated that sparsely distributed wild plants in agricultural areas were not particularly beneficial for pollinators. However, the considerable bee species richness ensures diet diversity. Several authors suggest that nutritional adequacy of the diet is related to nutrient diversity, and diet variety enhances insect life cycles, preventing them from many chronic diseases (e.g. Alaux et al., 2015).

We found a high diversity of anemophilous species, mainly graminoids, in the field margins. Unfortunately, since they usually do not produce nectar, the grasses and other anemophilous species provide little value to bees. In most cases, due to morphological properties, the pollen of anemophilous species is less attractive for bees compared to the pollen of entomophilous species. It has been confirmed by microscopic analysis (Stawiarz, 2009) that insects collect pollen from anemophilous flowers, though the insects' interest in anemophilous pollen is occasional and usually caused by lack of other more attractive forage (Denisow, 2011).

The multivariate ordination models demonstrated that composition and richness of the bee flora in the field margins was influenced primarily by the surrounding vegetation. The variations in species composition reflected the ability of particular species to migrate from surrounding habitats and to be plant species come established on field margins. The habitat type is considered to have an impact on the species composition while habitat heterogeneity is assumed to be the main predictor for plant species richness in the landscape scale (Köchy and Rydin, 1997). The highest bee species richness in field 
margins close to forests or meadows confirms the importance of natural habitats as the main natural sources of diaspores in the agricultural landscape (Beatty, 1991). The constant linear decrease in the number of bee-species as the distance increased from the natural habitats indicates that bee plants have limited dispersal ability. Although the most frequent dispersal mechanism was anemochory ( $86 \%$ of the bee species), considered as one of the most effective modes, the process of colonisation of field margins along the measured environmental gradient (habitat type-distance) was slowed down. This process reflects one of the most common plant properties - that a majority of seeds are placed close to the mother plants (Harper, 1977).

Bee species abundance was also related to the field size. The decrease of species diversity noted on field margins adjacent to big fields is alarming. We can predict a permanent decrease of bee species in intensely managed agricultural landscape. This is due to the fact that the trend towards consolidation of small and mid-size fields in areas of large acreage will presumably continue due to the technological and economical conditions of crop production.

We found that most bee species belonged to the family Asteraceae and the family Fabaceae. Some studies report that Asteraceae and Fabaceae plants are among the plant families most frequently visited by many bee species for nectar and pollen (Lagerhöf et al., 1992; Denisow, 2011). Additionally, some Fabaceae and Asteraceae species have a long flowering period. Since these species are perennials, they are available as year-to-year repeatable food (Kołtowski and Jabłoński, 2001; Kołtowski, 2006). However, in our study, only 5 Fabaceae species formed dense patches (Coronilla varia, Medicago falcata, Trifolium medium, T. repens, Vicia cracca). These species are regarded as a good source of nectar and pollen (Kołtowski, 2006; Denisow, 2011). According to Fussell and Corbet (1992), due to flower morphology, Fabaceae species are particularly important for bumblebees. Only two species from the Asteraceae family were found to create dense patches. One of them, Taraxacum officinale, is a particularly good source of both nectar and pollen (Warakomska, 2002), but it flowers for only a short time; reduced to two-three weeks during early spring on field margins. The other species, Achillea millefolium, is a poor nectar source, but a valuable pollen source, because it blooms for an extended time - from June until September (Denisow, 2011). Among important forage sources, we documented Berteroa incana (Brasicaceae). Crucifers are recom- mended to improve food sources for a variety of insect visitors, not only Apoidea (Fussell and Corbet, 1992; Denisow, 2011). Similarly, Apiaceae species (Pastinaca sativa, Daucus carota) and Euphorbia cyparissias were found to occur abundantly. These species attract a variety of insect groups (Wróblewska, 1993; Zych, 2007; Denisow, 2009; 2011). We also observed Rubus caesius flowering abundantly in the field margins. Rubus caesius is a good source of nectar and pollen over an extended period of time and attractive to a variety of insects (Kołtowski, 2006; Denisow and Wrzesień, 2007). Therefore, we can assume that field margin flora may support the biodiversity improvement of many pollinator groups; however, actions ensuring large dense patches of these plants are indispensable.

Our results also suggest focusing on the natural habitats in order to maintain and enhance forage continuity in the agricultural landscape. At the beginning of the season, during the early spring and spring periods, there is not much flowering of bee species on field margins. The main rewarding resources are availableduringsummer. These findings agree with the statements of Steffan-Dewenter et al. (2005) and Corbet (2000), who emphasize that when no flowering crops are available, then the natural, semi-natural, and anthropogenic vegetation, all together, represent a source of continuous forage for wild bees in the agricultural landscape. The important goal should be to increase a heterogeneous landscape, and first of all, to preserve the current natural and semi-natural habitats adjacent to crop fields. Such a straightforward opinion is promoted by many authors (Banaszak, 1992; Delaplane and Mayer, 2000; Marshall and Moonen, 2002). However, sowing of flower-rich seed mixes is also recommended in active management of unfavourable landscapes (Carreck and Williams, 1997; Corbet, 2000; Kołtowski and Jabłoński, 2001; Decourtye et al., 2010). Such activity is supported in many EU countries through the agri-environmental programs (Potts et al., 2011), but unfortunately not in Poland.

\section{CONCLUSIONS}

In conclusion, bee species richness and abundance on field margins benefits from the location of natural habitats, especially if the distance is $<1000 \mathrm{~m}$ or if the field acreage is $<10 \mathrm{ha}$. The shift from heterogeneous habitats to a more homogeneous landscape causes a reduction in bee floral diversity. Due to lack of dense bee-species patches, the promotion of sowing by nectar- and pollen- rich bee species seems 
to be a reasonable management activity across field margins, which may potentially contribute to the pollinators' nutrition and to supporting the conservation of pollinators in the surroundings of farms.

\section{ACKNOWLEDGEMENTS}

We thank our two anonymous Reviewers for their comments which improved the manuscript. This research was supported financially by the Ministry of Science and Higher Education of Poland as a part of statutory activities of the Department of Botany (project OKB/DS/2), University of Life Sciences in Lublin, and the Department of Geobotany, Institute of Biology and Biochemistry, Maria Curie-Skłodowska University.

\section{REFERENCES}

Alaux C., Ducloz F., Crauser D., Le Conte Y. (2015) Diet effects on honeybee immunocompetence. Biology Letters 6: 562-565. DOl: 10.1098/rsbl.2009.0986

Banaszak J.(1992) Strategy for conservation of wild bees in an agricultural landscape. Agriculture Ecosystems and Environment 40: 179-192.

Bartomeus I., Potts S. G., Steffan-Dewenter I., Vaissière B. E., Woyciechowski M., Krewenka K. M., Tscheulin T., Roberts S. P. M., Szentgyörgyi H., Westphal C., Bommarco R. (2014) Contribution of insect pollinators to crop yield and quality varieswith agricultural intensification. Peer] 2:e328: DOl 10.7717/peerj.328

Beatty S. W. (1991) Colonization dynamics in a mosaic of landscape: the buried seed pool. Journal of Biogeography 18: 553-563.

Braun-Blanquet J. (1 964) Pflanzensoziologie. Grundzüge der Vegetationskunde. Springer-Verlag. Wien and New York. 865 pp.

Carreck N. L., Williams I. H. (1997) Observations on two commercial flower mixtures as food sources for beneficial insects in the UK. Journal of Agricultural Research 128(4): 397-403.

Chmielewski T., Węgorek T. (2003) Rolnicza przestrzeń produkcyjna a różnorodność biologiczna. In: Andrzejewski R., Weigle A. (Eds.) Różnorodność biologiczna Polski. Narodowy Fundusz Ochrony Środowiska. Warszawa: 203-210.
Corbet S. A. (2000) Conserving compartments in pollination webs. Conservation Biology 14: 129-131.

Decourtye A., Mader E., Desneux N. (2010) Landscape enhancement of floral resources for honey bees in agroecosystems. Apidologie 41: 264-277.

Delaplane K. S., Mayer D. F. (2000) Crop pollination by bees. CABI Publishing. New York. 344 pp.

Denisow B. (2009) Pollen production, flowering and insect visits on Euphorbia cyparissias L. and Euphorbia virgultosa Klok. Journal of Apicultural Research 48: 50-59.

Denisow B. (201 1) Pollen production of selected ruderal plant species in the Lublin area. University of Life Sciences Press. Lublin. 86 pp.

Denisow B., Wrzesień M. (2007) The anthropogenic refuge areas for bee flora in agricultural landscape. Acta Agrobotanica 60: 147-157.

Fussell M., Corbet S. A. (1992) Flower usage by bumblebees: a basis for forage plant management. Journal of Applied Ecology 29: 451-465. DOl: 10.2307/2404513

Gallai N., Salles J. M., Settele J., Vaissiere B. E. (2009) Economic valuation of the vulnerability of world agricultural confronted with pollinator decline. Ecological Economics 68: 810-821.

Harper J. L. (1977) Population biology of plants. Academic Press. London. 892 pp.

Johnson R. M., Ellis M. D., Mullin C. A., Frazier M. (2010) Pesticides and honey bee toxicity - USA. Apidologie 41: 312-331.

Kevan P. G. (1999) Pollinators as bioindicators of the state of the environment: species, activity and diversity. Agriculture, Ecosystems and Environment 74: 373-393.

Kleijn D., van Langevelde F. (2006) Interesting effects of habitat quantity and quality on insects. Basic and Applied Ecology 7: 201-214.

Kleyer M., Bekker R. M., Knevel I. C., Bakker J., Thompson K., Sonnenschein M., Poschlod P., Van Groenendael J. M., Klimeš L., Klimešová J., Klotz S., Rusch G. M., Hermy M., Adriaens D., Boedeltje G., Bossuyt B., Dannemann A., Endels P., Götzenberger L., Hodgson J. G., Jackel A-K., Kühn I., Kunzmann D., Ozinga W. A., Römermann C., Stadler M., 
Schlegelmilch J., Steendam H. J., Tackenberg O., Wilmann B., Cornelissen J. H. C., Eriksson O., Garnier E., Peco B. (2008) The LEDA Traitbase: A database of life-history traits of the Northwest European flora. Journal of Ecology 96:1266-1274.

Kochy M., Rydin H. (1997) Biogeography of vascular plants on habitat islands, peninsulas and mainlands in an east-central Swedish agricultural landscape. Nordic Journal of Botany 17: 215-223.

Kołtowski Z. (2006) Wielki atlas roślin miododajnych. Wydanie Rzeczpospolita. Warszawa. 327 pp.

Kołtowski Z., Jabłoński B. (2001) Attempt to develop an assortment of herbaceous honey-producing plants to be used for the improvement of bee pastures on idle lands. Journal of Apicultural Science 45: 21-28.

Kovach W. L. (2005) MVSP - A MultiVariate statistical package for windows, ver. 3.1. Kovach Computing Services. Pentraeth, Wales, U.K. 138 pp.

Lagerhöf J., Stark J., Svensson B. (1992) Margins of agricultural field as habitats for pollinating insects. Agriculture Ecosystems and Environment 40: 117 -124.

Lonsdorf1 E., Kremen C., Ricketts T., Winfree R., Williams N., Greenleaf S. (2009) Modelling pollination services across agricultural landscapes. Annals of Botany 103(9): 1589-1600.

Marshall E. J. P., Moonen A. C. (2002) Field margins in northern Europe: their functions and interactions with agriculture. Agriculture, Ecosystems and Environment 89: 5-21.

Mirek Z., Piękoś-Mirkowa H., Zając A., Zając M. (2002) Flowering plants and pteridophytes of Poland. A checklist. Biodiversity of Poland, vol. 1. W. Szafer Institute of Botany, Polish Academy of Sciences. Kraków. 442 pp.

Potts S. G., Roberts S. P. M., Dean R., Marris G., Brown M. A., Jones R., Neuman P., Settele J. (2010). Declines of managed honey bees and beekeepers in Europe. Journal of Apicultural Research 49: 15-22.

Stanisz A. (2007) Przystępny kurs statystyki z zastosowaniem Statistica na przykładach z medycyny. Statsoft Polska. Kraków. 359 pp.
Statistica v. 10 (2011) StatSoft Inc.

Stawiarz E. (2009) Pollen of non-nectariferous plants in the microscopic image of honeys of some communes of the Świętokrzyskie Voivodeship. Acta Agrobotanica 62(2):53-58.

Steffan-Dewenter I., Potts S. G., Packer L. (2005). Pollinator diversity and crop pollination services are at risk. Trends in Ecology and Evolution 20: 651-652.

ter Braak C. J. F., Šmilauer P. (2012) Canoco reference manual and user's guide: software for ordination, version 5.0. Microcomputer Power. Ithaca, USA. 496 pp.

Turski R., Uziak S., Zawadzki S. (1993) Środowisko przyrodnicze Lubelszczyzny. Lubelskie Towarzystwo Naukowe. Lublin. 106 pp.

Warakomska Z. (2002) The honey and pollen from dandelion (Taraxacum Zinn em. Web). Annales UMCS, sectio EEE 10: 107-112.

Westphal C., Steffan-Dewenter I., Tscharntke T. (2003) Mass flowering crops enhance pollinator densities at a landscape scale. Ecology Letters 6: 961-965.

Wróblewska A. (1993) Flowering and pollen value of selected species of umbelliferous family - Umbelliferae Juss. (Apiaceae Lindl.) in Lublin region. Part II. Pollen efficiency and insect visit. Acta Agrobotanica 46(1): 51-65.

Wrzesień M., Denisow B. (2007) The phytocoenoses of anthropogenically transformed areas with a great importance for Apoidea. Acta Agrobotanica 60: 1 17-126.

Zarzycki K., Trzcińska-Tacik H., Różański W., Szeląg Z., Wokek J., Korzeniak U. (2002) Ecological indicato values of vascular plants of Poland. W. Szafer Institute of Botany, Polish Academy of Science. Kraków. 183 pp.

Zych M. (2007) On flower visitors and true pollinators: The case of protandrous Heracleum sphondylium $L$. (Apiaceae). Plant Systematics and Evolution 263: 159 179. 